\title{
Electrooxidation of Se on nanodispersed films of titanium dioxide modified with $\mathrm{ZnO}$ and $\mathrm{Au}$
}

\author{
Myroslava M. Plakhotna ${ }^{a}$, Vera S. Vorobets ${ }^{\mathrm{b} *}$, Gennadii Ya. Kolbasov ${ }^{\mathrm{b}}$, Natalia P. Smirnova ${ }^{\mathrm{c}}$, \\ Oksana P. Linnik ${ }^{\mathrm{c}}$, Anna M. Eremenko ${ }^{\mathrm{c}}$ \\ aNational university of “ Kyiv-Mohyla academy”, 2 G. Skovoroda Str., 04070 Kyiv, Ukraine \\ ${ }^{\mathrm{b}}$ V.I.Vernadskii Institute of General and Inorganic Chemistry, National Academy of Sciences of \\ Ukraine, 32/34 Acad. Palladin Str., 03680 Kyiv, Ukraine
}

${ }^{c}$ Chuiko Institute of Surface Chemistry, National Academy of Sciences of Ukraine, 17 General Naumov Str., 03164 Kyiv, Ukraine

contactinge-mail:vorobetsvs@i.ua

Keywords: selenium, electrooxidation, $\mathrm{TiO}_{2}$, gold nanoparticles.

Selenium electrooxidation process on $\mathrm{TiO}_{2}$ and $\mathrm{TiO}_{2} / \mathrm{ZnO}$ electrodes, modified by gold nanoparticles, was investigated in solutions of sulfuric, chloric and citric acids. It is shown that $\mathrm{TiO}_{2} / \mathrm{ZnO} / \mathrm{Au}$ electrodes can be used as indicator electrodes at the determination of selenium by anodic stripping voltammetry method. Optimum conditions of selenium (IV) determination are: supporting solution $0,001 \mathrm{M} \mathrm{H}_{2} \mathrm{SO}_{4}$, electroconcentrating potential $-(1,3 \div 1,5) \mathrm{V}$; time of electrolysis $120 \mathrm{~s}$, scanning speed of potential $20 \mathrm{mV} / \mathrm{s}$.

\section{Introduction}

Selenium is an important technological and biological element used both in industry and in medicine[1]. It is used in semiconductor technology, pulp and paper industry, manufacture of fertilizers, nonferrous metallurgy. The main peculiarity of selenium consist in the existence of a nice distinction between its useful and toxic content, which necessitates the use of highly sensitive and accurate techniques for the determination of its concentration. The stripping voltammetry (SV) method satisfies these requirements[2-8], because it has incontestable advantages over other methods: it has a high sensitivity and selectivity, rapid response to changes in the composition of the analyzed object, is easy to automate. This method does not require expensive analytical equipment and can be used in laboratory, industrial and field conditions. Cathodic stripping voltammetry is most frequently employed to determine selenium, using hanging mercury drop electrode, mercuryfilm electrode, mercury-graphite electrode, thick-film graphite electrode, silver electrode, silver disk electrode as indicator electrodes [24]. Disadvantages of the cathodic voltammetry for determination of selenium are the interfering 
effect of oxygen and the need to remove it from solution during analysis, as well as the use of toxic mercury electrodes. The anodic SV method using gold indicator electrodes has no above disadvantages. However, the complexity of gold electrodes making and their short service life [5-8], as well as the interfering effect of chloride ions, are significant disadvantages of this method, which greatly limits its use in the analysis of real objects for selenium content. This paper presents results of studying $\mathrm{TiO}_{2^{-}}$and $\mathrm{TiO}_{2} / \mathrm{ZnO}-$ electrodes modified by gold nanoparticles, which are easy to make, are cheap and have a long service life for Se (IV) determination by anodic stripping voltammetry method. This method of selenium determination is based on the process of selenium electrooxidation. The method consists in previous electroconcentrating of selenium (0) in cathodic potential range and its subsequent electrodissolution in anodic potential range.

\section{Experimental part}

Electrode materials were $\mathrm{TiO}_{2}$ and $\mathrm{TiO}_{2} / \mathrm{ZnO}$ based films doped with $\mathrm{Au}$ nanoparticles prepared as described in [9]. Mesoporous $\mathrm{TiO}_{2}$ and $\mathrm{TiO}_{2} / \mathrm{ZnO}$ films were obtained, using titanium tetra-isopropoxide and zinc acetate as metal sources and triblock copolymer Pluronic P123 as templating agent. Gold-modified films were prepared using two techniques. Namely, thermoinduced reduction of $\mathrm{Au}^{3+}$ ions added to the precursor as $\mathrm{HAuCl}_{4}$ aqueous solution with the following calcinations at $500^{\circ} \mathrm{C}$ signing here as $s-g$ and photoreduction of $\mathrm{Au}^{3+}$ ions deposited on mesoporous $\mathrm{TiO}_{2}$ and $\mathrm{TiO}_{2} / \mathrm{ZnO}$ films from aqueous solution $\mathrm{HAuCl}_{4}$ under UV-irradiation followed by heat treatment at $20-550{ }^{\circ} \mathrm{C}$ signing as ads. The use of these techniques makes it possible to form in $\mathrm{TiO}_{2}$ and $\mathrm{TiO}_{2} / \mathrm{ZnO}$ films gold nanoparticles of different sizes with different distributions on the surface $((a d s)-$ Au NPs are distributed on the surface; $(s-g)$ - Au NPs are distributed in the matrix) [10].

The effect of doping $\mathrm{Au}$ on the electrocatalytic activity of films in the reaction of selenium electrooxidation were investigated. A current wave, which was observed on anodic voltammograms in the potential range $+(0,6 \div 0,8) \mathrm{V}$, was used as the analytical signal of selenium (IV). The voltammograms were recorded as follows. The solution under investigation containing $\mathrm{Se}(\mathrm{IV})$ ions was placed in an electrochemical cell. A potential $\left(E_{e}\right)$ was applied to the indicator electrode, and electrolysis was carried out for $60 . . .180 \mathrm{~s}$ with stirring of the solution. The electrolysis potential was varied between $-0,2$ and $-1,6 \mathrm{~V}$. The current-potential curve of anodic electrooxidation of selenium (0) obtained by electrolysis was recorded with potential variation from 0 to $+1.0 \mathrm{~V}$ at a rate of $20 \mathrm{mV} / \mathrm{s}$.

The photoelectrochemical properties of the $\mathrm{TiO}_{2} / \mathrm{ZnO}, \quad \mathrm{TiO}_{2} / \mathrm{Au}$ and $\mathrm{TiO}_{2} / \mathrm{ZnO} / \mathrm{Au}$ electrodes were estimated using the spectral dependence of the photoelectrochemical current 
( $i_{p h}$ [11]. The $i_{p h}$ spectra were expressed in the units of quantum efficiency (electron/photon).

\section{Results and discussion}

The photoelectrochemical characteristics (flat-band potential $\mathrm{E}_{\mathrm{fb}}$ and band gap energy $\mathrm{E}_{\mathrm{g}}$ ) of electrodes based on $\mathrm{TiO}_{2}$ and $\mathrm{TiO}_{2} / \mathrm{ZnO}$ films as a function of their composition and the method of modification by gold nanoparticles are listed in Table 1. It follows from Table 1 that the flat-band potential $\mathrm{E}_{\mathrm{fb}}$ differs insignificantly for the modified samples, which means a small change in the potential drop in the space charge region after the modification. The band gap energy $E_{g}$ for the modified samples was somewhat different, depending on the method of modification.

Table 1. Values of flat-band potential $\mathrm{E}_{\mathrm{fb}}$ and band gap energy $\mathrm{E}_{\mathrm{g}}$ for $\mathrm{TiO}_{2} / \mathrm{Au}$ and $\mathrm{TiO}_{2} / \mathrm{ZnO} / \mathrm{Au}$ electrodes as a function of films composition in the solution $0,001 \mathrm{M}$ $\mathrm{H}_{2} \mathrm{SO}_{4}: 0,001 \mathrm{M} \mathrm{KCl}: 0,1 \mathrm{mg} / \mathrm{L} \mathrm{H}_{2} \mathrm{SeO}_{3}$.

\begin{tabular}{|c|c|c|c|}
\hline & Composition & $\mathrm{E}_{\mathrm{fb}}, \mathrm{V}$ & $\mathrm{E}_{\mathrm{g}}, \mathrm{eV}$ \\
\hline 1 & $\mathrm{TiO}_{2} / \mathrm{Au}_{(a d s)}$ & -0.30 & 3.25 \\
\hline 2 & $\mathrm{TiO}_{2} / 1 \% \mathrm{ZnO} / \mathrm{Au}_{(a d s)}$ & -0.50 & 3.25 \\
\hline 3 & $\mathrm{TiO}_{2} / 4 \% \mathrm{ZnO} / \mathrm{Au}_{(a d s)}$ & -0.60 & 3.25 \\
\hline 4 & $\mathrm{TiO}_{2} / 3 \% \mathrm{Au}_{(s-g)}$ & & 3.40 \\
\hline 5 & $\mathrm{TiO}_{2} / 1 \% \mathrm{ZnO} / \mathrm{Au}_{(s-g)}$ & -0.56 & 3.60 \\
\hline 6 & $\mathrm{TiO}_{2} / 4 \% \mathrm{ZnO} / \mathrm{Au}_{(s-g)}$ & -0.56 & 3.70 \\
\hline 7 & $\mathrm{TiO}_{2} / \mathrm{Au}_{(s-g)} \mathrm{Termo}$ & -0.62 & 3.60 \\
\hline
\end{tabular}

The increase in $E_{\mathrm{g}}$ values observed for the samples synthesized by sol-gel method can be explained by the Burstein-Moss effect [12], where the apparent band gap of a semiconductor is increased due to the shift of absorption edge to higher energies as a result of all states close to the conduction band being populated.
In [10] we showed that, the maximum observed at around 530-600 $\mathrm{nm}$ on the optical absorption spectra of $\mathrm{Au}$ containing $\mathrm{TiO}_{2}$ and $\mathrm{TiO}_{2} / \mathrm{ZnO}$ films can be assigned to the surface plasmon resonance (SPR) of spatially confined electrons in $\mathrm{Au}$ nanoparticles (NPs), and confirms the reduction of $\mathrm{Au}^{3+}$ ions to the $\mathrm{Au}^{0}$ state. According to the XRD data, $\mathrm{TiO}_{2}$ and $\mathrm{TiO}_{2} / \mathrm{ZnO}$ films had an anatase crystal structure but $\mathrm{TiO}_{2} / \mathrm{Au}$ films had an anatase crystal structure with cubic $\mathrm{Au}$ crystals [10]. In $\mathrm{TiO}_{2} / \mathrm{ZnO} / \mathrm{Au}_{(s-g)}$ films, a cubic $\mathrm{Zn}_{2} \mathrm{Ti}_{3} \mathrm{O}_{8}$ phase was also observed. Au NPs with a mean diameter of $10-30 \mathrm{~nm}$ were found in $\mathrm{TiO}_{2} / \mathrm{Au}_{(s-}$ g) and $\mathrm{TiO}_{2} / \mathrm{ZnO} / \mathrm{Au}_{(s-g)}$ films prepared by consequent photo- and thermoreduction while the particle sizes of $\mathrm{TiO}_{2} / \mathrm{ZnO} / \mathrm{Au}_{(a d s)}$ samples rose to $100 \mathrm{~nm}$. For the $\mathrm{Au}$ containing films obtained by thermoreduction (without UVirradiation), the particle size near $300 \mathrm{~nm}$ are observed [10].

Sulfuric, nitric, perchloric and citric acids were used as a supporting electrolyte for Se (IV) determination by anodic stripping voltammetry. It has been found that selenium (IV) electrooxidation current is affected by the nature of acid anion and $\mathrm{pH}$ value of the supporting electrolyte. At $\mathrm{pH}$ of supporting solution over 5.5, Se (IV) electrooxidation current is not observed. Decreasing pH solution to 4 leads to an increase in electrooxidation current and its better reproducibility. The largest value of selenium electrooxidation current was observed 
in sulfuric acid solutions. At an acid concentration in the supporting electrolyte of $0,001 \mathrm{M}$, which corresponds to $\mathrm{pH}=3.0$, the analytical signal of Se (IV) had the same appearance but a different height in supporting electrolytes based on sulfuric, nitric and perchloric acids, decreasing in the order $\mathrm{H}_{2} \mathrm{SO}_{4}$ $>\mathrm{HClO}_{4}>\mathrm{HNO}_{3}$.

Further increase of acid concentration, and hence - decreasing the background solution $\mathrm{pH}$ causes an increase the value of the background current and a shift of potential at the onset of dissolution of gold nanoparticles from the electrode surface towards more negative potentials. This leads to a decrease in sensitivity of electrodes and to worse reproducibility of selenium electrooxidation current.

Analytical signal of Se (IV) in sulfuric acid based electrolytes was observed in the potential range $+(0,60-0,70) \mathrm{V}$, and for electrolytes based on citric and perchloric acids at in potentials of about $+0.80 \mathrm{~V}$. At these potentials, the anodic voltammograms in seleniumcontaining solutions exhibited a current wave (Figure 1).

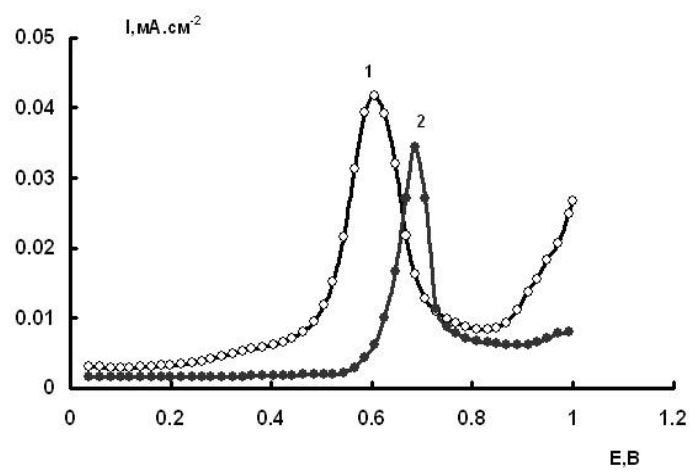

Figure 1. Anodic voltammograms in sulfuric acid solution (0,001M H $\left.\mathrm{SO}_{4}: 0,001 \mathrm{M} \mathrm{KCl}: 0,1 \mathrm{mg} / \mathrm{L} \mathrm{H}_{2} \mathrm{SeO}_{3}\right)$ at electrodes:

$1-\mathrm{TiO}_{2} / 1 \% \mathrm{ZnO} / \mathrm{Au}_{(s-g)}$ 2

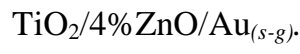

The anodic polarization curves were recorded after cathodic electroconcetration of solutions at potential of $-1.2 \mathrm{~V}$ (vs silverchloride electrode) for $2 \mathrm{~min}$. The current wave on anodic polarization curves at potentials of $(0.6 \div 0.8)$ (Figure 1) is an analytical signal of Se (IV) and is caused by electrooxidation of $\mathrm{Se}^{0}$,

$$
\mathrm{Se}^{0}+3 \mathrm{H}_{2} \mathrm{O}-4 \mathrm{e} \leftrightarrows \mathrm{H}_{2} \mathrm{SeO}_{3}+4 \mathrm{H}^{+},
$$

which is formed in the investigated solution as a result of cathodic electroconcentration [13].

It has been found that selenium electrooxidation potential and analytical signal height of selenium dependent on the modification method and the composition of films, which were used as sensitive layer of working electrode (Table 2).

Table 2. Values of selenium electrooxidation potential $\mathrm{E}_{\mathrm{Se} 0}$ and selenium electrooxidation current $\mathrm{I}_{\mathrm{Se} 0}$ for $\mathrm{TiO}_{2} / \mathrm{Au}$ and $\mathrm{TiO}_{2} / \mathrm{ZnO} / \mathrm{Au}$ electrodes as a function of films composition in the solution $0,001 \mathrm{M} \mathrm{H}_{2} \mathrm{SO}_{4}$ : 0,001 $\mathrm{M} \mathrm{KCl}: 0,1 \mathrm{mg} / \mathrm{L} \mathrm{H}_{2} \mathrm{SeO}_{3}$.

\begin{tabular}{|c|c|c|c|}
\hline & Composition & $\mathrm{E}_{\mathrm{Se} 0}, \mathrm{~V}$ & $\mathrm{I}_{\mathrm{Se} 0}, \mathrm{~mA}$ \\
\hline 1 & $\mathrm{TiO}_{2} / \mathrm{Au}_{(a d s)}$ & $>0.70$ & - \\
\hline 2 & $\mathrm{TiO}_{2} / 1 \% \mathrm{ZnO} / \mathrm{Au}_{(a d s)}$ & $>0.70$ & - \\
\hline 3 & $\mathrm{TiO}_{2} / 4 \% \mathrm{ZnO} / \mathrm{Au}_{(a d s)}$ & $>0.70$ & - \\
\hline 4 & $\mathrm{TiO}_{2} / 3 \% \mathrm{Au}_{(s-g)}$ & 0.72 & $1,5 \cdot 10^{-3}$ \\
\hline 5 & $\mathrm{TiO}_{2} / 1 \% \mathrm{ZnO} / \mathrm{Au}_{(s-g)}$ & 0.60 & $4,2 \cdot 10^{-2}$ \\
\hline 6 & $\mathrm{TiO}_{2} / 4 \% \mathrm{ZnO} / \mathrm{Au}_{(s-g)}$ & 0.70 & $3,1 \cdot 10^{-2}$ \\
\hline 7 & $\mathrm{TiO}_{2} / \mathrm{Au}_{(s-g)} \mathrm{Termo}$ & - & - \\
\hline
\end{tabular}

As seen from Figure 1, decreasing of $\mathrm{ZnO}$ content from $4 \%$ to $1 \%$ in $\mathrm{TiO}_{2} / \mathrm{ZnO} / \mathrm{Au}$ films with a uniform distribution of gold 
nanoparticles in the matrix of the film leads to shift of selenium electrooxidation potential $\mathrm{E}_{\mathrm{Se} 0}$ towards more negative values and to increase in the selenium oxidation current I Se0 (Table 2 samples 5 and 6; Figure 1).

At the electrodes of the compositions $\mathrm{TiO}_{2} / \mathrm{ZnO} / \mathrm{Au}_{(a d s)}$ and $\mathrm{TiO}_{2} / \mathrm{Au}_{(a d s)}$ (Table 2, samples 1-3) with Au nanoparticles, distributed on the surface of films and at the electrodes $\mathrm{TiO}_{2} / \mathrm{Au}_{(s-g)}$ (Table 2, sample 4) with $\mathrm{Au}$ nanoparticles distributed in the matrix, the selenium electrooxidation current wave overlapped with the current wave of dissolution of gold nanoparticles from the electrode surface, which is manifested at potentials of $>0.8 \mathrm{~V}$ in sulfuric acid based electrolytes (Figure 2). The electrodes containing $1 \% \mathrm{ZnO}$ in $\mathrm{TiO}_{2} / \mathrm{ZnO} / \mathrm{Au}$ films with a uniform distribution of gold nanoparticles in the matrix of the film showed the best catalytic activity (Table 2, sample 5).

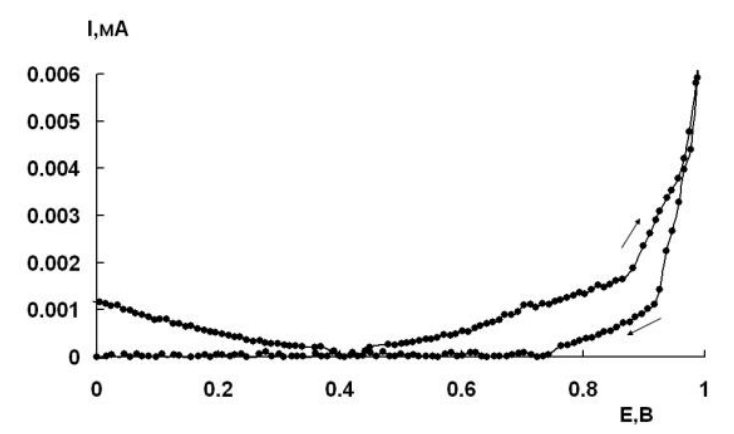

Figure 2. Anodic voltammograms (forward and reverse scan) for $\mathrm{TiO}_{2} / \mathrm{Au}_{(\text {ads })}$ electrodes with gold nanoparticles distributed over the surface of films (Table 1, sample 1) in sulfuric acid based electrolyte $(0,001 \mathrm{M}$ $\mathrm{H}_{2} \mathrm{SO}_{4}$ : 0,001 M KCl: 0,1 mg/l $\mathrm{H}_{2} \mathrm{SeO}_{3}$ ).

The decrease in the activity $\left(\mathrm{ISe}_{\mathrm{Se}}\right)$ of $\mathrm{TiO}_{2}$ and $\mathrm{TiO}_{2} / \mathrm{ZnO}$ samples with gold nanoparticles distributed on the surface (Table 2, samples 13 ) in comparison with the samples 5 and 6 (Table 2) may be a result of enlargement of gold NPs and their nonuniform distribution on the surface, since it has been found that the smallest size of gold NPs localized in the nearsurface layer of the film is observed for $\mathrm{TiO}_{2} / \mathrm{ZnO} / \mathrm{Au}_{(s-g)}$ films [10]. For $\mathrm{TiO}_{2} / \mathrm{ZnO}_{(s-g)}$ electrodes with gold nanoparticles distributed in matrix, the flat-band potential does not change on increasing $\mathrm{ZnO}$ content from 1 to $4 \%$ (Table 1, samples 5 and 6), whereas the band gap energy increases from 3.6 to $3.7 \mathrm{eV}$. This indicates a shift in the position of the valence band in the anodic side and may point to a better catalytic activity of these materials compared to unmodified $\mathrm{TiO}_{2}$ in photooxidation processes, which was confirmed by us in selenium electrooxidation reaction as an example.

The electrooxidation current depended on selenium concentration, electroconcentration conditions and electrolyte composition.

Thus, the use of $\mathrm{TiO}_{2} / \mathrm{ZnO}$ electrodes modified by gold NPs makes it possible to determine the selenium (IV) content in solutions by anodic stripping voltammetry. Optimum conditions of selenium (IV) determination are: background solution $0,001 \mathrm{M} \quad \mathrm{H}_{2} \mathrm{SO}_{4}$, electroconcentrating potential $-(1,3-1,5) \mathrm{V}$; time of electrolysis $120 \mathrm{~s}$, scanning speed of potential $20 \mathrm{mV} / \mathrm{s}$. By means of this method it is possible to determine the concentration of $\mathrm{Se}$ (IV) within $(0,02-0,40) \mathrm{mg} / \mathrm{L}$. 


\section{References}

[1] Ragozzino G, Tanzilli V, Cristiano NMV, Guarino G, Mattera E. Selenium: Properties and Clinical Applications. A Systematic Review. Int $\mathrm{J}$ Clin Endocrinol. 2017;1(1): 008-0017.

[2] Nazarenko I.I., Ermakov A.N. Analiticheskaya khimiya celena i tellura (Analytical chemistry of selenium and tellurium). Moscow: Nauka; 1971. $252 \mathrm{p}$.

[3] Ochsenkuhn_Petropoulou M., Tsopelas F. Speciation analysis of selenium using voltammetric techniques. Anal. Chim. Acta 2002; 467(1):167-178.

[4] Lange B., Van Den Berg C.M.G.

Determination of selenium catalytic cathodic stripping voltammetry. Anal. Chim. Acta 2000; 418(3): 33-42.

[5] Ting_guo Wu, Wei_zhi Xiang, Fu_zheng Zhang, Jia_gi Deng. Differential anodic stripping voltammetric determination of selenium in hair and flour at a gold film electrode. Analyst 1988; 113: 1431-1433.

[6] Andrews R.W., Johnson D.C. Voltammetric deposition and stripping of selenium (IV) at a rotating gold_disk electrode in $0.1 \mathrm{M}$ perchloric acid. Analytical chemistry 1975; 478(2): 294-299.

[7] Pereira C.F., Gonzaga F.B., et al. Determination of $\mathrm{Se}(\mathrm{IV})$ by anodic stripping voltammetry using gold electrodes made from recordable CDs. Talanta 2006; 69: 877-881.

[8] Tan S.H., Kounaves S.P. Determination of selenium (IV) at a microfabricated gold ultramicroelectrode array using square wave anodic stripping voltammetry. Electroanalysis 1998; 10(6): 364368.

[9] V. Vorobets, E. Manujlov, Y. Gnatyuk, N. Smirnova, G. Kolbasov, A. Eremenko. Electro- and photocatalytic properties of electrodes based on mesoporous $\mathrm{TiO}_{2}-\mathrm{ZnO}-\mathrm{Ag}$ films. Chemistry, Physics and Technology of Surface 2008; 14:382-390.

[10] N.Smirnova, V.Vorobets, O.Linnik, E.Manuilov, G.Kolbasov, A.Eremenko. Photoelectrochemical and photocatalytical properties of mesoporous $\mathrm{TIO}_{2}$ films modified with silver and gold nanoparticles. Surf. Interface Anal. 2010; 6-7(42):12051208.

[11] Smirnova, Y. Gnatyuk, A. Eremenko, G. Kolbasov, V. Vorobets, I. Kolbasova, O. Linyucheva. Photoelectrochemical characterization and photocatalytic properties of mesoporous $\mathrm{TiO}_{2} / \mathrm{ZrO}_{2}$ Films. International Journal of Photoenergy 2006; 1:224-229.

[12] Marius Grundmann. The Physics of Semiconductors. Springer-Verlag Berlin Heidelberg: Springer; 2006. 690 p. doi: 10.1007/3-540-34661-9

[13] V.Vorobets. Opredelenie selena (IV) na $\mathrm{TiO}_{2}-\mathrm{Au}$ elektrode metodom anodnoj inversionnoj voltamperometrii (Determination of Selenium (IV) on $\mathrm{TiO}_{2}-\mathrm{Au}$ electrode by anodic stripping voltammetry). Ukrainian Chemistry Journal 2014; 80(11):32-35 . 